
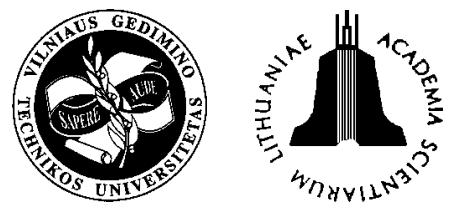

\title{
ROLLING STOCK PLANNING FOR PASSENGER TRANSPORTATION
}

\author{
Jonas Butkevičius ${ }^{1}$, Leonas Povilas Lingaitis ${ }^{2}$, Gediminas Vaičiūnas ${ }^{3}$ \\ ${ }^{1}$ Dept of Transport Management, Vilnius Gediminas Technical University, \\ Plytines g. 27, LT-10105 Vilnius-16, Lithuania.E-mail:vladas@ti.vtu.lt \\ ${ }^{2,3}$ Dept of Railway Transport, Vilnius Gediminas Technical University, J. Basanavičiaus g. 18, \\ LT-13224 Vilnius-09, Lithuania. ${ }^{2}$ E-mail: leonasl@ti.vtu.lt 33E-mail:vaic@ti.vtu.lt
}

Received 2004-03-25; accepted 2004-06-30

\begin{abstract}
The planning of the optimal rolling stock for passenger carriage should be based on passenger flow forecasts, close examination of the available locomotives and cars and properly chosen methods of their writing off and plans for rolling stock renewal.

The strategy of renewing the existing rolling stock for passenger transportation (including plans for writing off, modernization and purchasing of cars and locomotives) is offered by the authors which is based on forecasts of passenger flow variation and expenses.
\end{abstract}

Keywords: passenger railway transport, forecasts of passenger flow, locomotive, carriage, the strategy of renewing rolling stock.

\section{Introduction}

Rolling stocks are used to carry loads and passengers by railway. After some time they get worn and obsolete. In freight transportation the wear of the locomotives is more important because their reliability decreases and maintenance costs increase, while for passenger trains the obsolescence is equally important, because, in this case, their comfort ability decreases.

The planning of the optimal rolling stocks for passenger carriage should be based on passenger flow forecasts, close examination of the available locomotives and cars and properly chosen methods of their writing off and plans for rolling stock renewal.

\section{Analysis of rolling stocks for passenger transpor- tation}

Passengers serviced by a joint-stock company 'Lietuvos geležinkeliai' are carried by passenger cars driven by the electric and diesel locomotives as well as by rail (diesel) cars.

In Fig 1, the prospective analysis of rolling stock service life for 2004-2014 is given.

The graph in Fig 1 shows that cars make the largest part of rolling stocks. The total number of passenger cars decreased from 327 to 200 , i.e. by $8 \%$ (Table 1) in the period from 1992 to 2003 . This is because the turnover of passengers decreased considerably.

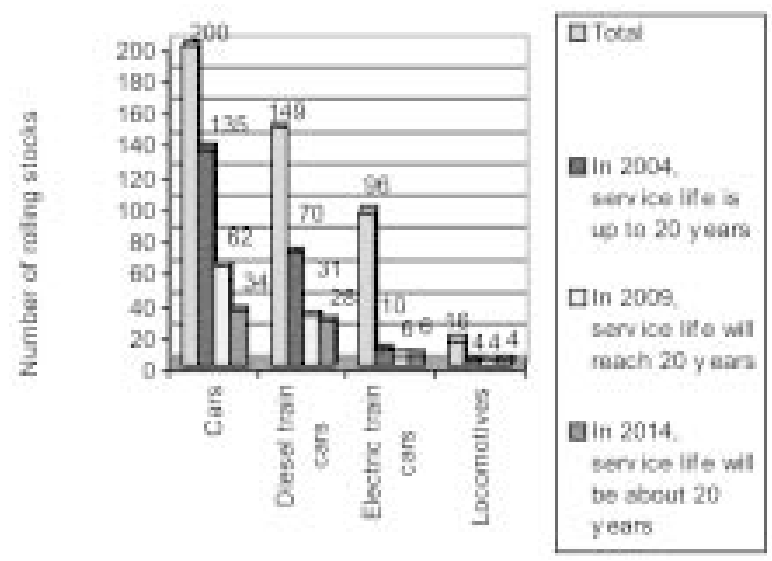

Fig 1. The replacement of the rolling stock according to the specified level of wearing in the period up to 2014

The distribution of the remaining cars according to their age varies to a great extent. It is shown in Fig 2.

About $50 \%$ of cars have been used for more than 15 years. Most of them (about $36 \%$ ) are in use for more than the time specified for their service.

The records of the electric trains are kept taking account of the number of their cars. Now the electric trains consist of 32 front cars (with the locomotive 
Table 1. The dynamic changes in the number of cars

\begin{tabular}{|c|c|c|c|c|c|c|c|c|c|c|c|}
\hline & \multicolumn{11}{|c|}{ Amount of cars } \\
\hline & 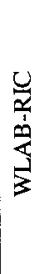 & 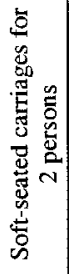 & 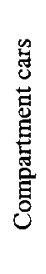 &  & 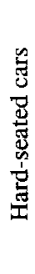 & 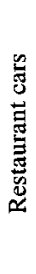 & 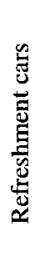 & 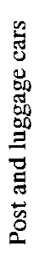 &  & 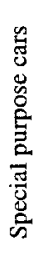 & 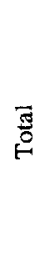 \\
\hline 1992 & - & 10 & 170 & 117 & 5 & 9 & 7 & 5 & 2 & 2 & 327 \\
\hline 1993 & - & 10 & 173 & 113 & 5 & 8 & 7 & 8 & 2 & 2 & 325 \\
\hline 1994 & 4 & 10 & 202 & 80 & 23 & 7 & 6 & 5 & 2 & 2 & 341 \\
\hline 1995 & 4 & 10 & 195 & 76 & 28 & 6 & 6 & 5 & 2 & 2 & 334 \\
\hline 1996 & 4 & 10 & 139 & 73 & 28 & 4 & 6 & 2 & 2 & 2 & 270 \\
\hline 1997 & 4 & 10 & 118 & 69 & 32 & 4 & 6 & 3 & 3 & 2 & 251 \\
\hline 1998 & 4 & 10 & 118 & 66 & 35 & 4 & 6 & 3 & 3 & 2 & 251 \\
\hline 1999 & 4 & 10 & 116 & 61 & 37 & 4 & 6 & 3 & 2 & 2 & 245 \\
\hline 2000 & 4 & 10 & 116 & 61 & 37 & 4 & 6 & 3 & 2 & 2 & 245 \\
\hline 2001 & 4 & 10 & 116 & 60 & 37 & 4 & 6 & 3 & 2 & 2 & 244 \\
\hline 2002 & 4 & 5 & 110 & 42 & 37 & 3 & 6 & 3 & 2 & 2 & 214 \\
\hline 2003 & 4 & 5 & 102 & 36 & 37 & 3 & 6 & 3 & 2 & 2 & 200 \\
\hline
\end{tabular}

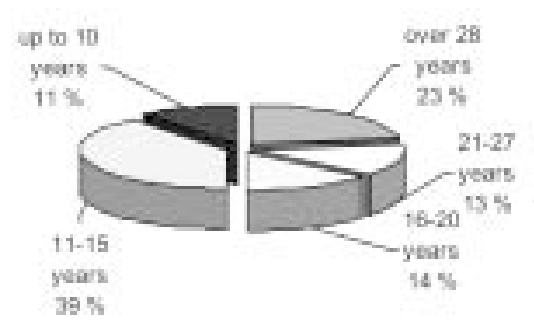

Fig 2. Distribution of passenger cars according to their service life, percent

driver's cabin), 53-engine cars and 26 trailer cars of ER9M locomotives (the total number of 111 cars).

All engine-cars of electric trains have been in service for more than 15 years, while most of them (41 car out of 53, i.e. more than $75 \%$ ) served for more than 25 years. Front cars are newer -6 cars (out of 32) served for less than 10 years, whereas 17 cars (making more than $50 \%$ ) were older than 25 years. Diesel locomotives are also considered taking account of the number of their cars. All 44 cars of DRIA diesel locomotives have been in service for less than 15 years, while those driven by 118D locomotives served for more than 15 years. However, 91 car out of the total number are older than 20 years. The latter should be written off by gradually replacing them with the new ones.

Diesel locomotives are used on the local routes for 144 hauls, covering the distance of $85 \mathrm{~km}$, while 10 pairs of locomotives run on $108 \mathrm{~km}$-long international routes.

Summing up the analysis of the available rolling stock it should be emphasized that $36 \%$ of electric train cars, and $35 \%$ of passenger train cars have already exceeded the specified service life of 20 years.

\section{The dynamics of the number of passengers carried by rail transport}

In 2003, the largest number of passengers was carried by railway on the international routes of Vilnius-Moscow (184 406), Vilnius - St. Petersburg 84 125, Vilnius - Minsk - 78 952, Vilnius - Warsaw 21 752, Vilnius - Simferopol (by trailer-cars not belonging to Lithuanian Railway) - 14 973, and Vilnius - Riga - 14874 [1].

Graphical representation of the above numbers of passengers is provided in Fig 3.

The proportion of passenger transportation by rail on the market of transport services in Lithuania has not changed during the last 6 years making $2.2 \%$. However, the proportion of passengers carried on international routes dropped from $56,5 \%$ to $49,7 \%$, with that on the local routes remaining unchanged. A relatively low percentage of local route passengers may be accounted for the availability of buses (and even trolleybuses in Vilnius and Kaunas) on these routes.

Passengers using railway transport on local routes are mainly students, workers and socially supported people. A special survey [1] has shown that the fore-

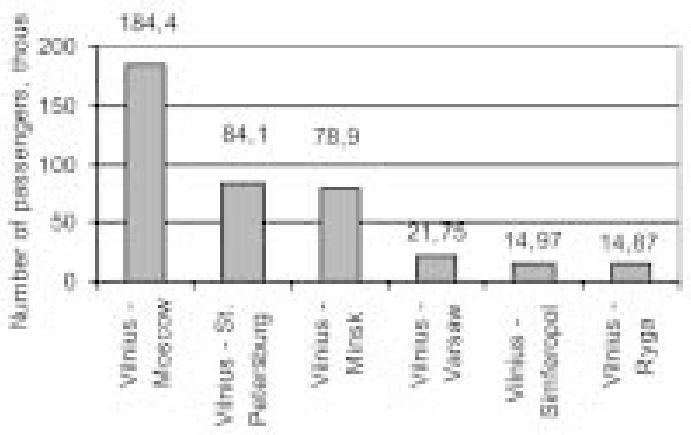

Fig 3. The number of passengers carried by Lithuanian railway on the main routes in 2003 
casts of the number of passengers carried by railway are in good agreement with the growth of the gross national product in Lithuania. In a general case, the problem of forecasting is stated as follows [2]: let $Y=$ $\left\{u\left(t_{i}\right)\right\}$ be a single-dimension time string of statistical observations made at equal time intervals $t_{i}$, when $i=1, \ldots, n$. The assignment is to find the values for a particular period of time in the future, i.e. the values corresponding to the moments $t_{j}$, where $j=n+1, \ldots$, $n+T$. In addition, it is assumed that the inertia of the process considered is keeping the same general trend in the future. The level of time sequence for the moment $t$ can be determined as the sum of two components.

$$
y=f(\Theta, t)+\varepsilon(t),
$$

here $f(\Theta, t)$ - a constant time function (trend); $\varepsilon(t)$ a random function assessing the irregular factors; parameter vector to be determined.

The function $f(\Theta, t)$ describes the main trends of the analyzed process assessing the effect of major factors on it. If we find $f(\Theta, t)$, which is a constant component of the process, then $(t)$, which is the remaining component, will be random, thereby proving that the process is stationary.

To determine $f(\Theta, t)$, the regression and correlation analyses are used. If variables $t, x, z$ and $y$ are interrelated (for example, $t$ - time period, $x$ - gross national product (GNP), $z$ - state income and $y$-number of passengers), then the following equation is obtained:

$$
y^{\prime}=a t^{2}+b t+c x^{2}+d x+e z^{2}+f z+g .
$$

When calculating the parameters $a, b, c, d, e, f$ and $g$ of the equation, a system of seven equations is solved. The calculations have shown that to make a forecast of the number of passengers carried by land transport such a parameter as GNP is the best, i.e. it is well correlating with all other factors considered (state income, average monthly payment, household income and expenditure, state wealth, cost index of manufacturers and consumers and variation of goods and services provided).

The regression equations used for developing a forecast are presented in Table 2. In these equations, $t_{1}$ is time factor and $x_{i}$ is the factor of gross national product. Not less than $95 \%$ of statistical values agree with the data obtained from the above equations to the accuracy of $\pm 5 \%$.

The forecasts of the passenger flows are based on the equations given in Table 2 and the allowance is made for the passenger flow increase $(15 \%)$ when the state joins the EU. The variation of the number of passengers carried in 1990-2003 and the forecast for the period up to 2015 are presented in Fig 4.
Table 2. Regression equations used in forecasting

\begin{tabular}{|c|l|c|}
\hline & \multicolumn{1}{|c|}{$\begin{array}{c}\text { Passenger } \\
\text { transportation }\end{array}$} & $\begin{array}{c}\mathrm{y}=-1,0509 \mathrm{E}-7 t_{i}^{2}- \\
23,5586 t_{i}+5,3104 \mathrm{E}-\end{array}$ \\
\hline 1 & $\begin{array}{l}\text { Transportation by } \\
\text { land transport } \\
\text { (total) }\end{array}$ & $7 x_{i}^{2}+2,9229 \mathrm{E}-16 x_{i}+10,28$ \\
\hline 2 & $\begin{array}{l}\text { Transportation by } \\
\text { local railways }\end{array}$ & $\begin{array}{c}\mathrm{y}=-7,2648 \mathrm{E}-8 t_{i}^{2}-0,0914 t_{i}+ \\
1,9871 \mathrm{E}-9 x_{i}^{2}+5,0336 \mathrm{E}- \\
16 x_{i}+0,0204\end{array}$ \\
\hline 3 & $\begin{array}{l}\text { Transportation by } \\
\text { international } \\
\text { railway }\end{array}$ & $\begin{array}{c}\mathrm{y}=-7,2611 \mathrm{E}-8 t_{i}^{2}-0,0647 t_{i}+ \\
1,3253 \mathrm{E}-9 x_{i}^{2}+5,0357 \mathrm{E}- \\
16 x_{i}+0,023\end{array}$ \\
\hline
\end{tabular}

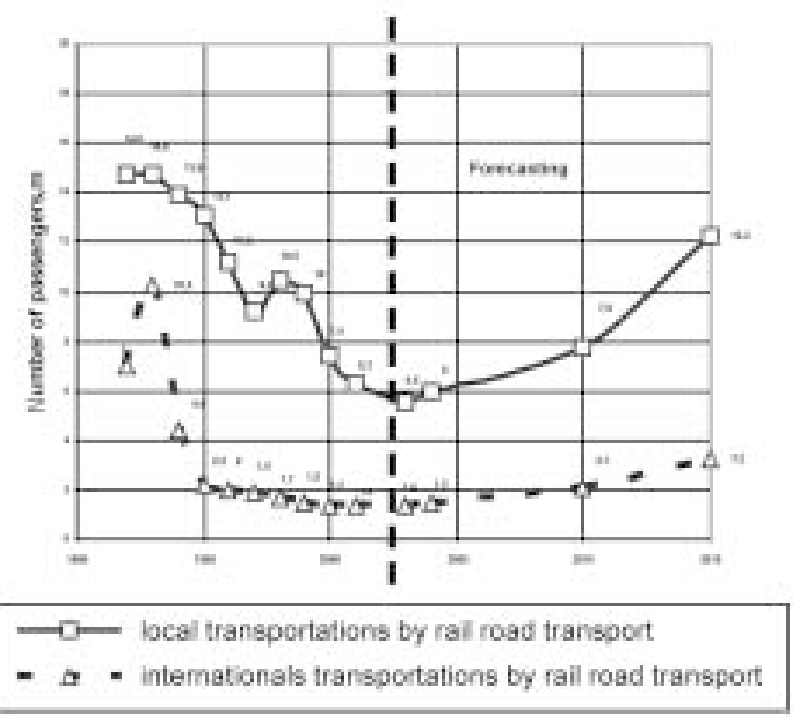

Fig 4. The variation of the number of passengers carried by railway in 1990-2003and the forecast for the period from 2003 to 2015

It is assumed that passenger transportation on the local routes will grow up to $7,8 \mathrm{~m}$ until the year 2010 , while on the international routes it will reach $3,2 \mathrm{~m}$ of passengers (the total number is about 15,4 $\mathrm{m})$. The volume of passenger transportation on local and international routes in 2015 is expected to grow by 1,9 and 2,9 times, respectively, compared with the year 2001. Based on this forecast, trends of further development may be predicted. With the methods of locomotive writing off known, a renewal plan developed and the above forecast available, it is possible to forecast the demand for rolling stocks.

\section{Methods used for writing off the locomotives}

The strategy of developing passenger transportation by rail relies on two major elements - writing 
off obsolete and worn out locomotives and developing the plan of rolling stock renewal. The latter includes major upgrading measures and purchasing of new cars and locomotives.

It is clear that the main reason for writing off cars is their wearing. Obsolescence is a relative criterion described in terms of the service life, attractiveness and comfortability of cars. In this respect all cars may be grouped according to their age and the stages of their writing off may be determined. At the first step, the time of the car's writing off should be defined not quite precisely, with only the number of cars to be taken out of service determined. The exact time may be fixed later, in several steps, taking into account the financial state of the enterprise. A special commission should make a decision upon the particular cars to be written off in the particular time basing itself on technical characteristics of cars and relative investments:

$$
i=r / l \text {, }
$$

here $r$ - overhaul expenses, Lt; $l$ - expected service life of a rolling stock after the overhaul, years ( $\mathrm{km}$ for traction rolling stocks)

The parameter $i$ is compared with the parameter $i_{n}$ of a new rolling stock in the following way:

$$
i_{n}=k_{n} / l_{n},
$$

here $k_{n}$ - the purchasing cost of a new rolling stock, $\mathrm{Lt}$; $l_{n}$ - expected service life of a new rolling stock, years (or $\mathrm{km})$.

If $i>i_{n}$, it means that a rolling stock should be replaced by a new one. An algorithm may be generated for making a list of rolling stocks to be written off:

1. a preliminary plan of passenger trains to be written off is made;

2. technical inspection of trains included in the above plan should be made;

3. the inspected trains are divided into those to be written off and those to be left in service;

4. trains to be modernized should be selected from those left for further use.

Traction rolling stocks, when achieving the limit of their service life, start wearing fast which results in higher fuel and oil consumption and a larger percentage of failures. Testing [3] has shown that the locomotives of TEP60 and TEP70 series begin to wear intensely after 30 years of service (or having run about 3,92 m $\mathrm{km}$ ). Such locomotives should rather be written off.

\section{A plan of rolling stock renewal}

Relying on the developed algorithm for writing off the locomotives as well as taking into account their age and actual technical state and a major concept of 'Lietuvos geležinkeliai' developed for passenger trains modernization, a general plan of rolling stock renewal and the investments needed may be drawn. The largest investments for car modernization are expected in the year 2008 (Fig 5) [4].

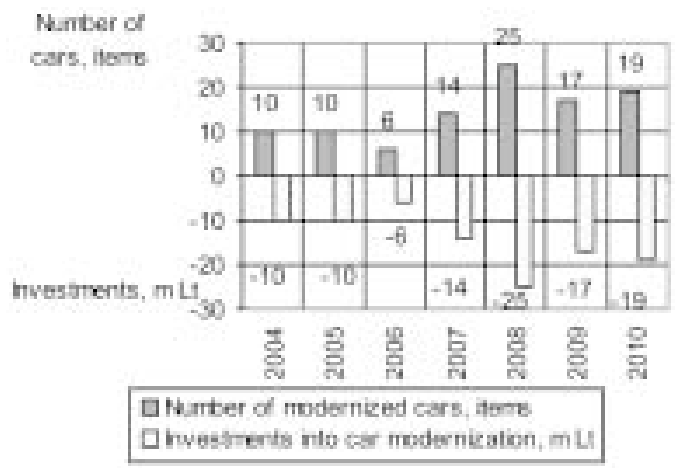

Fig 5. A plan for car modernization

A modernization plan for diesel trains has been drawn based on the developed renewal algorithm and the expected flow of passengers. This plan is given in Fig 6.

Measures to be taken in the coming years to renew the existing rolling stock are provided in Figs 7-9. These plans may be altered in the future, the changes depending on the financial state of the company and the dynamics of the locomotive and car wearing.

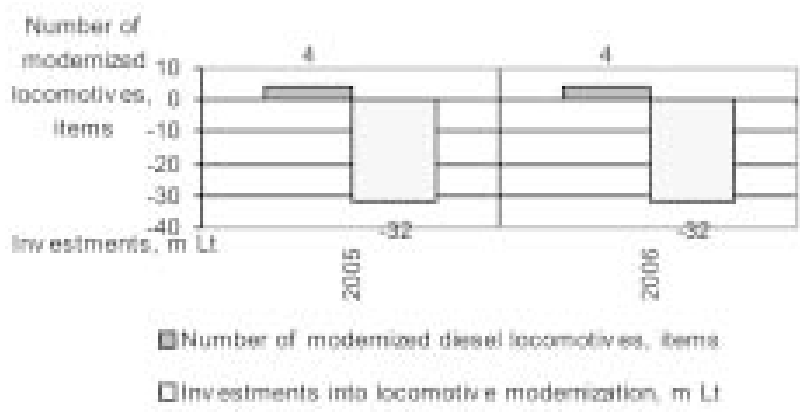

Fig 6. A plan of diesel locomotive modernization

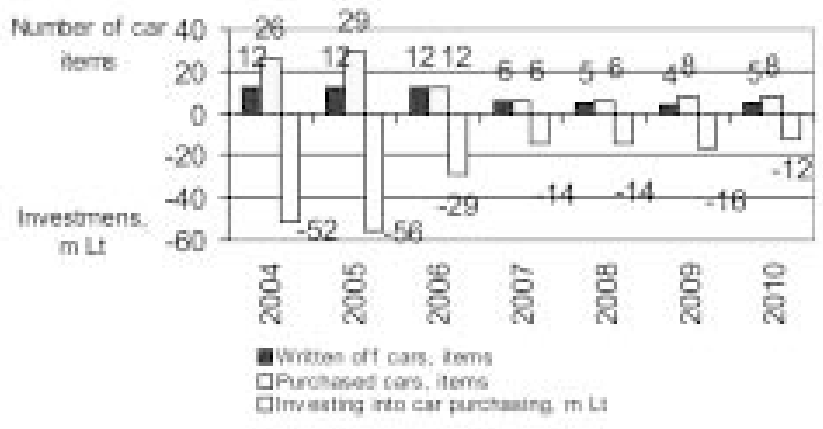

Fig 7. A plan of writing off old cars and purchasing of new cars 


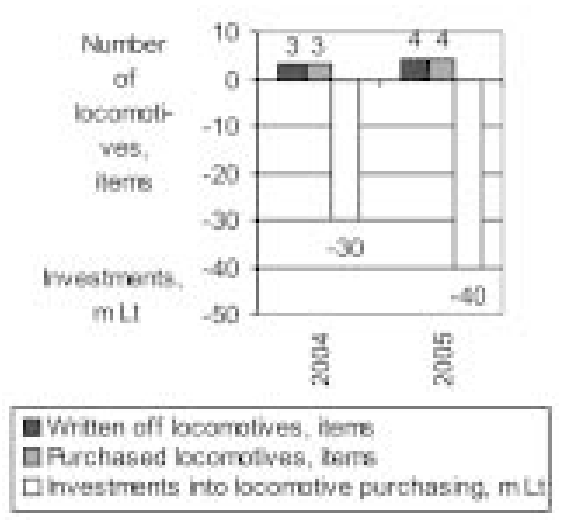

Fig 8. A plan of writing off old locomotives and purchasing of new locomotives

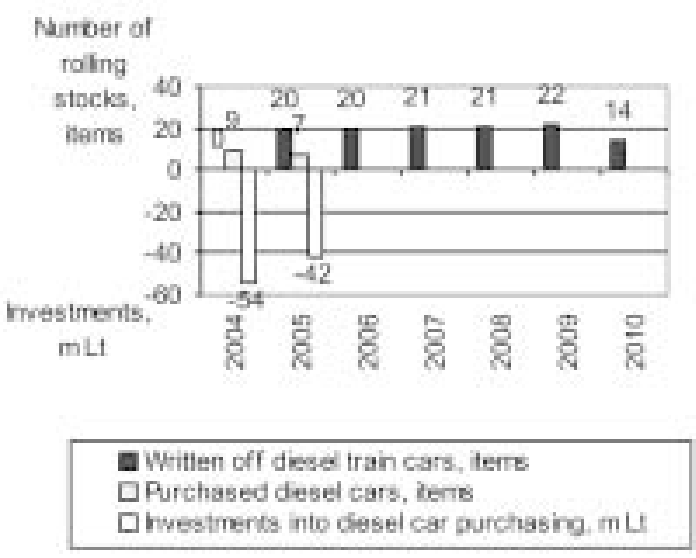

Fig 9. A plan of writing off diesel locomotives and purchasing rail (diesel) cars

One can see in Figs 7-9, that the largest amount of rolling stocks should be purchased in 2004 and 2005. The numbers relating to purchasing diesel train cars and rail (diesel) cars are not correct, because the capacity of diesel trains is used by passengers only by about 20-30 \% now. Besides, rail (diesel) cars may be used more effectively by varying their coupling in the train.

\section{Economic effect of passenger trains renewal}

The results obtained in the profitability analysis (the economic effect) of the development of transportation by rail transport (including the evaluation of income from this kind of transport and the investments into the rolling stock maintenance and renewal) are presented in Fig 10.

In Fig 10, one can see that the expected losses are decreasing. This may be accounted for the future growth of the number of passenger flows. The losses are the highest in the years 2004 and 2005, because this is the time when new locomotives and passenger cars are purchased.

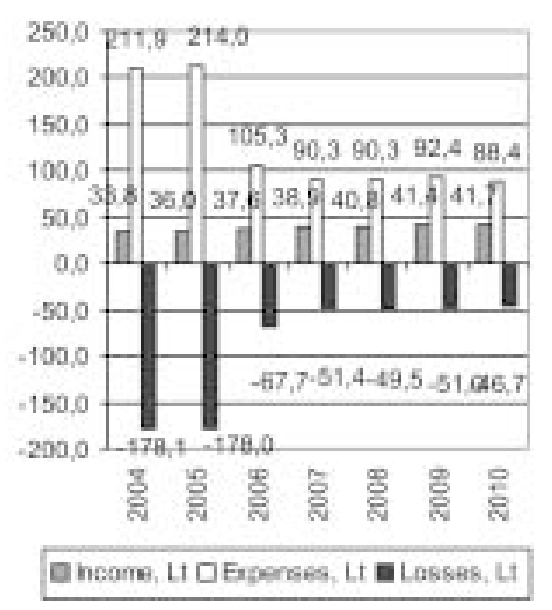

Fig 10. Economic effect of rolling stock renewal

\section{Conclusions}

1. During the last decade the number of passenger cars dropped from 327 to 200 , i.e. by $35 \%$. This was caused by the decrease of passenger flow by about 3 times.

2. About $36 \%$ of passenger cars, $56 \%$ of diesel trains and $86 \%$ of electric train cars exceeded the specified service life of 20 years.

3. The strategy of renewing the existing rolling stocks for passenger transportation (including plans for writing off, modernization and purchasing of cars and locomotives) is offered by the authors which is based on forecasts of passenger flow variation and the expenses.

4. The profitability analysis has shown that the losses in passenger transportation by rail may be avoided only by increasing the number of passengers. Proper management is also essential with the emphasis placed on using the appropriate number of cars on particular routes.

\section{References}

1. Butkevičius, J. Passenger transportation (Keleivių vežimai). Monograph. Vilnius: Technika, 2002. 416 p. (in Lithuanian).

2. Yang, W.-H.; Mathur, K.; Ballou, R. H. Stochastic Vehicle Problem with Restocking. Transportation Science, 34, 2000, p. 99-112.

3. Lingaitis, L. P.; Bureika, G.; Vaičiūnas, G.; Juršėnas, V. The reliability and ageing control of rolling stocks. Vilnius: Technika, 2003. 58 p. (in Lithuanian).

4. Lingaitis, L. P.; Butkevičius, J.; Vaičiūnas, G. Strategic planning of passenger transportation by rail transport. Vilnius: Technika, 2003. 125 p. (in Lithuanian). 